ORIGINAL ARTICLE

\title{
Epidemiological and clinical aspects of snakebites in the upper Juruá River region, western Brazilian Amazonia
}

\author{
Ageane Mota da SILVA ${ }^{1,2}$, Mônica COLOMBINI ${ }^{3}$, Ana Maria MOURA-DA-SILVA ${ }^{3}$, \\ Rodrigo Medeiros de SOUZA4, Wuelton Marcelo MONTEIRO5,6, Paulo Sérgio BERNARDE*i) \\ Instituto Federal do Acre (IFAC), Campus de Cruzeiro do Sul, Estrada da APADEQ no 1.192, Bairro Nova Olinda, 69.980-000, Cruzeiro do Sul. Acre, Brazil \\ Universidade Federal do Acre (UFAC), Programa de Pós-Graduação Bionorte, Campus Universitário, BR 364 Km 04, Distrito Industrial, 69.915-900, Rio Branco, Acre, Brazil \\ Instituto Butantan, Laboratório de Imunopatologia, Av. Vital Brazil 1500, Butantã, 05503-900, São Paulo, SP, Brazil \\ ${ }^{4}$ Universidade Federal do Acre (UFAC), Campus Floresta, Laboratório de Microbiologia, Imunologia e Parasitologia, Estrada do Canela Fina S/N, Gleba Formoso, \\ 69.980-000, Cruzeiro do Sul, Acre, Brazil \\ Universidade do Estado do Amazonas (UEA), Av. Djalma Batista 3578, Flores, 69050-010, Manaus, AM, Brazil \\ ${ }^{6}$ Fundação de Medicina Tropical Dr. Heitor Vieira Dourado, Av. Pedro Teixeira s/n, Dom Pedro, 69040-000, Manaus, AM, Brazil \\ Universidade Federal do Acre (UFAC), Campus Floresta, Laboratório de Herpetologia, Estrada do Canela Fina S/N, Gleba Formoso, 69.980-000, Cruzeiro do Sul, Acre, Brazil \\ * Corresponding author: SnakeBernarde@hotmail.com; (D) https://orcid.org/0000-0002-2191-7817
}

\begin{abstract}
This study addresses the clinical and epidemiological aspects of envenoming cases resulting from snakebites treated at a hospital in Cruzeiro do Sul, in the upper Juruá River region, western Brazilian Amazonia. The specific identity of snakes that caused the envenomings was inferred (a) from the diagnosis of patient symptoms and signs upon hospital admission, (b) by enzyme immunoassay for detection of Bothrops atrox and Lachesis muta venom from serum samples taken from patients before antivenom therapy, or (c) by direct identification of the snake, when it was brought along to the hospital or photographed. There were 133 snakebites (76.2 cases per 100,000 inhabitants) registered during one year (July 2017 to June 2018). Most snakebites (88.7\%) were caused by Bothrops spp., and the rest by non-venomous snakes or dry bites. Snakebites tended to occur more often during the rainy season, coinciding with the period of greater reproductive activity of the snakes and greater availability of their prey. In addition, the increase in the water level of rivers and lakes during the rainy season tends to concentrate snakes in dry places and, thus, to increase encounters with humans. Information campaigns on prevention and first aid, specially among the most vulnerable groups (indigenous people, farmers, and children and teenagers in rural areas), and the importance of using protective equipment (boots, leggings, leather gloves) in certain high risk activities (e.g. agriculture and extractivism in forests) are fundamental for the reduction of snakebite morbidity.
\end{abstract}

KEYWORDS: venomous animals; snakes; envenoming; Acre; Bothrops atrox; enzyme immunoassay

\section{Aspectos clínicos e epidemiológicos de acidentes ofídicos na região do Alto Juruá, oeste da Amazônia brasileira}

\section{RESUMO}

Este estudo aborda os aspectos clínicos e epidemiológicos dos envenenamentos ofídicos tratados em um hospital em Cruzeiro do Sul, Acre, resultantes de acidentes que ocorreram na região do Alto Juruá, no oeste da Amazônia brasileira. A identidade específica das serpentes que causaram os envenenamentos foi inferida (a) pelos sinais e sintomas apresentados pelo paciente na admissáo hospitalar, (b) por imunoensaio enzimático para detecçáo de veneno de Bothrops atrox e Lachesis muta em amostras de soro retiradas de pacientes antes da soroterapia, e (c) pela identificação direta da serpente, quando esta foi levada para o hospital ou fotografada. Houve 133 casos (76,2 casos por 100.000 habitantes) de acidentes ofídicos registrados durante um ano (julho 2017 a junho 2018). A maioria das picadas de serpentes (88,7\%) foi causada por Bothrops spp., e o restante por espécies náo peçonhentas ou "picadas secas". Os acidentes ofídicos tenderam a ocorrer com maior frequência durante a estação chuvosa, coincidindo com o período de maior atividade reprodutiva das serpentes e maior disponibilidade de suas presas. Além disso, o aumento dos níveis de rios e lagos pode fazer com que esses animais procurem locais mais secos, aumentando a frequência de encontro com seres humanos. Campanhas educativas sobre prevenção e primeiros socorros, principalmente entre os grupos mais vulneráveis (indígenas, agricultores, crianças e adolescentes em áreas rurais), e sobre a importância da utilização de equipamentos de proteção (botas, perneiras, luvas de couro) em determinadas atividades de maior risco (e.g., agricultura e extrativismo em florestas), são fundamentais para reduzir a morbidade de picadas de serpentes.

PALAVRAS-CHAVE: animais peçonhentos; serpentes; envenenamentos; Acre; Bothrops atrox; imunoensaio enzimático 


\section{INTRODUCTION}

Snakebites are a neglected health problem on a global scale, specially in Africa, Asia, and Latin America (Gutiérrez 2014; Chippaux 2017; Williams et al. 2019). There are an estimated 2.7 million cases of snake envenoming per year on the planet, resulting in 81,000 to 138,000 deaths, and 400,000 cases of amputation and other permanent sequels (Williams et al. 2019). The envenomings are concentrated in rural areas, where hundreds of millions of people depend on agriculture or subsistence hunting and gathering to survive, living alongside snakes, and running the risk of suffering snakebites on a daily basis (Sharma et al. 2004; Rahman et al. 2010; Mise et al. 2019). In Latin America, despite considerable efforts in some countries to prevent and treat snakebites, and to train staff in the management of envenomings, there still remain major challenges to reduce snakebite morbity (Gutiérrez 2014).

In Brazil, 406 species of snakes are known, of which 67 belong to the families Elapidae and Viperidae, which are considered to be venomous (Costa and Bérnils 2018; Bernarde et al. 2018) and are involved in cases of snakebites, which amount to approximately 28,000 cases per year (Bernarde 2014). The greatest diversity of venomous snakes in Brazil is found in the Amazon region (34 species) (Costa and Bérnils 2018; Bernarde et al. 2018a), where the highest incidence of snakebites is recorded, accounting for an average of 46.51 cases per 100,000 inhabitants per year during 2010-2015 (Magalhäes et al. 2018). Snakebites are considered a neglected health problem in Brazilian Amazonia, where the great distance between the site of the snakebite and the nearest healthcare provider causes frequent delay in the administration of antivenom therapy, increasing the severity of the envenoming (Feitosa et al. 2015a; 2015b; Souza et al. 2018). Despite the advances in healthcare for snakebites in Brazil, availability and accessibility to antivenom is not uniform with respect to the most vulnerable parts of the population, particularly, those who live in remote areas in Brazilian Amazonia (Fan and Monteiro 2018). More realistic and comprehensive healthcare programs for the most vulnerable groups, such as indigenous groups in remote reserves, and the availability of the lyophilized form of antivenoms are needed in order to reduce the high morbidity and mortality rates associated with snakebites (Mendonça-da-Silva et al. 2017).

Bothrops Wagler, 1824 snakebites are the most frequent in Amazonia (81\% of cases; Magalhães et al. 2018), being caused mainly by Bothrops atrox L. (Feitosa et al. 2015a). Bothrops atrox is the most abundant venomous snake, both in forested and anthropized environments (Cunha and Nascimento 1993; Oliveira and Martins 2001), which increases the encounter frequency and the probability of being bitten by this species (Pardal et al. 2004; Waldez and Vogt 2009; Roriz et al. 2018). The name attributed to B. atrox in the Brazilian state of Acre ("surucucu") may cause an overestimation of cases of lachetic snakebites, because the same name is assigned to the snake Lachesis muta L. (Bernarde and Gomes 2012; Mota-da-Silva et al. 2019a). Indeed, lachetic envenoming is the second most frequent in Amazonia (7.4\%; Magalhães et al. 2018), accounting for $0.3 \%$ to $2.2 \%$ of cases in regional epidemiological studies (e.g., Pardal et al. 2004; Moreno et al. 2005; Lima et al. 2009; Roriz et al. 2018). The lower frequency of lachetic bites is probably due to the low population density of L. muta, which requires forested habitats and is less aggressive than B. atrox (Bernarde 2014). Crotalic snakebites, caused by the rattlesnake (Crotalus durissus L.), are the third most frequent (4.4\%) in Amazonia (Magalhães et al. 2018). The latter species is rather associated with savanna habitats, which limits its distribution and occurrence in the Amazon region (Santos et al. 2019). The fourth type of envenoming in Amazonia is caused by coral snakes of the genus Micrurus Wagler, 1824, with a low frequency $(0.3 \%$; Magalhães et al. 2018), mainly due to the lower frequency of human encounters with coral snakes, due to their secretive habits and lower abundance and the lower inoculating capacity of the Micrurus bite (Bernarde 2014).

In the upper region of the Juruá River, a right-hand tributary of the Amazonas River in the extreme western part of the Brazilian Amazon, snakebites are a significant public health problem, as cases are frequent, mainly in rural and forested areas, during agriculture and extractivism activities (Pierini et al. 1996; Bernarde and Gomes 2012; Mota-da-Silva et al. 2019b). In the present study, we monitored snakebite cases treated over one year in a hospital in Cruzeiro do Sul, the main urban center in the upper Juruá region, and evaluated the clinical and epidemiological aspects of the envenoming.

\section{MATERIAL AND METHODS}

\section{Study area}

The study was conducted during a one-year period (July 1 , 2017 to June 30, 2018) at the Juruá Regional Hospital in the municipality of Cruzeiro do Sul (Acre) $\left(07^{\circ} 37^{\prime} 51^{\prime \prime} \mathrm{N}\right.$, $\left.72^{\circ} 40^{\prime} 12^{\prime \prime} \mathrm{W}\right)$, located in the upper Juruá region in the western Brazilian Amazonia. This hospital regularly treats victims of snakebites from four municipalities (Cruzeiro do Sul, Mâncio Lima, and Rodrigues Alves in the state of Acre, and Guajará in the state of Amazonas), comprising an area of $24,806 \mathrm{~km}^{2}$ (Figure 1). The upper Juruá region has over $90 \%$ primary forest cover (ACRE 2010). The region has a total population of 137,722 inhabitants, mostly concentrated in the urban area $(72 \%)$, the rest living in rural areas, including forests (IBGE 2019). The main economic activities in the region are the production of manioc flour, extractivism of forest products (palm fruits), agriculture (corn, rice, beans, banana, watermelon and vegetables), livestock and fishing (ACRE 2010). The climate of the region is tropical, hot, and humid, with an annual average temperature of $24.5^{\circ} \mathrm{C}$ (ACRE 2010), with the highest rainfall period from November to April (average annual rainfall of 2500 $\mathrm{mm}$ ), coinciding with the period of the highest level of the Juruá River (Moreira et al. 2019). 


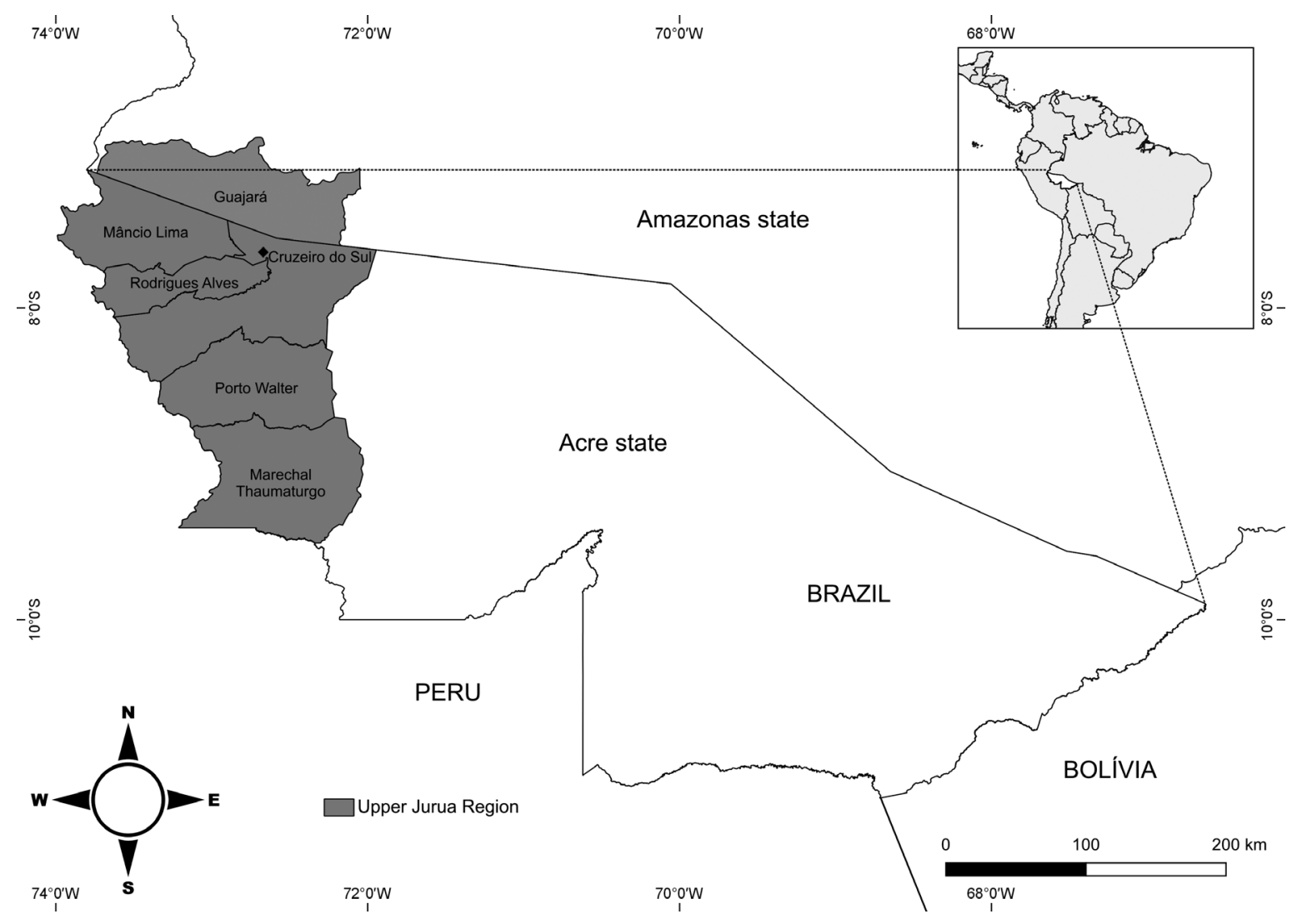

Figure 1. Location of the upper Juruá River region in Brazil. The municipalities belonging to the upper Juruá river are shown in gray.

\section{Snake identification}

The specific identity of snakes that caused the envenomings was obtained (a) from the diagnosis of patient symptoms and signs upon hospital admission, (b) by enzyme immunoassay for detection of Bothrops atrox and Lachesis muta venom from serum samples taken from patients before antivenom therapy, and (c) by direct identification of the snake, when it was brought along to the hospital or photographed.

The snakes, when taken to the hospital or photographed, were identified using a regional snake identification guide (Bernarde et al. 2017). When the snakes were not brought to the hospital, a panel containing photographs of snakes was shown to the patient to assess whether he or she recognized the species responsible for the envenoming. This was not a primary criterion for diagnosing the type of envenoming, but served as complementary information (see Mota-da-Silva $e t$ al. 2019a). The board contained color photographs of 17 common species in the upper Juruá region (Bernarde et al. 2017) featured in the following order of appearance: Boa constrictor, Eunectes murinus, Bothrops bilineatus smaragdinus, Spilotes pullatus, Lachesis muta, B. atrox (adult), Corallus batesii, Micrurus lemniscatus, Oxyrhopus melanogenys, M. hemprichii, M. annellatus bolivianus, B. atrox (juvenile), Epicrates cenchria, Anilius scytale, Oxybelis fulgidus, M. surinamensis,
Erythrolamprus aesculapii and E. reginae. In the panel, species were only indicated by letters from A to R. There were two contiguous photographs of each species on the panel, to test for consistency in the identification of the species. For Bothrops atrox there were four photographs (two of juveniles and two of adults). The snakebite cases in which the snake was not taken to the hospital and the patient was asymptomatic and had no change in blood coagulation time were considered "dry bites" or caused by non-venomous snakes (Silveira and Nishioka 1992; Nicoleti et al. 2010).

\section{Clinical manifestations}

The clinical and laboratorial data regarding the manifestations from the envenoming of the victims were obtained from the observation of patients and medical records. The Lee-White coagulation test was done in duplicate in a laboratory of the hospital.

The severity of bothropic envenomations was classified according to the following criteria (Ministério da Saúde 2016): mild (pain and edema of up to one segment, mild or absent bleeding, present or absent coagulopathy); moderate (twosegment pain and edema; mild or absent bleeding; present or absent coagulopathy); and severe (three-segment pain and edema or at least one of the following systemic complications: severe bleeding, hypotension / shock or acute renal failure, coagulopathy present or absent). 


\section{Venom-specific enzyme immunoenzymatic assays}

Immunoenzymatic assays (ELISA) were used to identify and quantify circulating Bothrops atrox or Lachesis muta venoms in serum samples according to Pardal et al. (2004). Venom toxins present in the samples were captured with BothropsLachesis antivenoms coated on ELISA plates. The plates were then incubated with a second antibody produced in rabbits for use in treating $B$. atrox venom or a specific mouse monoclonal antibody anti-Lachesis muta venom (Colombini et al. 2001) for reaction with bound toxins. This step was followed by incubation with anti-rabbit or anti-mouse IgGperoxidase conjugates. Reactions were revealed by addition of the enzyme substrates (OPD plus $\mathrm{H}_{2} \mathrm{O}_{2}$ ) and recorded at 492 $\mathrm{nm}$. Values were calculated using standard curves with known concentrations of $B$. atrox or L. muta venom. The cut-off level corresponded to the mean plus 2 SD values of negative samples obtained from volunteer donors accompanying the patients.

\section{Statistical analysis}

Monthly values of rainfall and water level of the Juruá River for the study period were obtained from the websites of the National Institute of Meteorology (INMET 2019) and the National Water Agency (ANA 2019), respectively, for a station in Cruzeiro do Sul. For statistical analysis purposes, only the cases that occurred in the municipalities that regularly send snakebite victims to the Juruá Regional Hospital were considered (Cruzeiro do Sul, Mâncio Lima, and Rodrigues Alves in the state of Acre, and Guajará in the state of Amazonas). The morbidity coefficient (cases per 100,000 inhabitants) was calculated by dividing the number snakebite patients during the study period by the number of inhabitants of the region and multiplying by 100,000 . We used Pearson's correlation to analyze the relationship between the number of monthly snakebites with rainfall and river level. The association between variable categories (Table 2) was analyzed by cross-reference, calculating the Pearson Chi-square test $\left(\chi^{2}\right)$. The significance level for all analyses was set at $\mathrm{P} \leq 0.05$.

\section{Ethical aspects}

This research is part of the project "Venomous snakes and snakebites in Cruzeiro do Sul region in the state of Acre" approved by the Committee of Ethics in Research with Humans of Fundação de Medicina Tropical Dr. Heitor Vieira Dourado (Authorization nr. 2,084,630). All patients gave written consent to participate in the study.

\section{RESULTS}

During the study period, 133 snakebite cases were treated at the Juruá Regional Hospital (Table 1), with a morbidity coefficient of 76.2 cases per 100,000 inhabitants in the upper Juruá region. Most of the snakebites were classified as bothropic (118 cases, $88.7 \%)$. The remaining cases were attributed to non-venomous snakes or to dry bites. In 20 cases (15\%), the snake that caused the bite was brought in with the patient or photographed
(13 Bothrops atrox and seven non-venomous snakes) (Figure 2). Bothrops atrox was recognized by $86.8 \%$ of the patients who saw the photo plates (79 of the 91 patients who saw the snake). Bothropic envenoming was confirmed by the enzymatic assay in 28 cases ( $29 \%$ of the cases, $n=97$ ). Crotalic, lachetic, and elapidic envenoming were not recorded. One death was recorded in the period $(0.7 \%$ lethality).

The cases treated at the Juruá Regional Hospital came mostly (86.4\%) from the municipalities of Acre state (AC), mainly from Cruzeiro do Sul (54 cases, 45.8\%), Mâncio Lima (21 cases, 17.8\%), and Rodrigues Alves (17 cases,

Table 1. Clinical and epidemiological characteristics of snakebite cases ( $n=$ 133) treated in the Juruá Regional Hospital in the Municipality of Cruzeiro do Sul, in the upper Juruá River region (western Brazilian Amazonia), from July 2017 to June 2018. Sample size available for each parameter is indicated in parentheses in each case. $\mathrm{N}$ cases $=$ number of cases.

\begin{tabular}{|c|c|c|}
\hline Parameter & $\mathrm{N}$ cases & Frequency (\%) \\
\hline \multicolumn{3}{|l|}{ Type of snakebite (133) } \\
\hline Bothropic & 118 & 88.7 \\
\hline Non-venomous/dry bite & 15 & 11.3 \\
\hline \multicolumn{3}{|l|}{ Season (120) } \\
\hline Rainy (Nov to Apr) & 79 & 65.8 \\
\hline Dry (May to Oct) & 41 & 34.2 \\
\hline \multicolumn{3}{|l|}{ Type of land use } \\
\hline Rural & 114 & 85.7 \\
\hline Urban & 19 & 14.3 \\
\hline \multicolumn{3}{|l|}{ Sex of snakebite victim } \\
\hline Masculine & 102 & 76.7 \\
\hline Feminine & 31 & 23.3 \\
\hline \multicolumn{3}{|l|}{ Age group } \\
\hline 0 to 10 & 15 & 11.3 \\
\hline 11 to 20 & 37 & 27.8 \\
\hline 21 to30 & 21 & 15.8 \\
\hline 31 to 40 & 28 & 21.0 \\
\hline 41 to 50 & 19 & 14.4 \\
\hline 51 to 60 & 8 & 6.0 \\
\hline$>60$ & 5 & 3.7 \\
\hline \multicolumn{3}{|l|}{ Occupation (133) } \\
\hline Farmer & 64 & 48 \\
\hline Student & 33 & 25 \\
\hline Housewife & 5 & 4.0 \\
\hline Other & 31 & 23 \\
\hline \multicolumn{3}{|l|}{ Time to hospital (133) } \\
\hline 0 to 1 hour & 16 & 12.0 \\
\hline 1 to 3 hours & 34 & 25.6 \\
\hline 3 to 6 hours & 29 & 21.8 \\
\hline 6 to 12 hours & 24 & 18.0 \\
\hline 12 to 24 hours & 15 & 11.3 \\
\hline$>24$ hours & 15 & 11.3 \\
\hline
\end{tabular}


Table 1. Continued.

\begin{tabular}{|c|c|c|}
\hline Parameter & $\mathrm{N}$ cases & Frequency (\%) \\
\hline \multicolumn{3}{|l|}{ Body part bitten (133) } \\
\hline Foot & 89 & 67.0 \\
\hline Leg & 23 & 17.0 \\
\hline Thigh & 2 & 1.6 \\
\hline Hand & 13 & 10.0 \\
\hline Arm & 2 & 1.5 \\
\hline Forearm & 1 & 0.7 \\
\hline Head & 1 & 0.7 \\
\hline Thorax & 2 & 1.5 \\
\hline \multicolumn{3}{|c|}{ Level of bothropic envenoming (118) } \\
\hline Mild & 59 & 50.0 \\
\hline Moderate & 43 & 36.5 \\
\hline Severe & 16 & 13.5 \\
\hline \multicolumn{3}{|c|}{ Physical symptoms/complications (118) } \\
\hline Pain & 110 & 93.2 \\
\hline Edema & 110 & 93.2 \\
\hline Bruising & 15 & 12.7 \\
\hline Bleeding at site of bite & 13 & 11.0 \\
\hline Blisters & 12 & 10.2 \\
\hline Secondary infection & 11 & 9.0 \\
\hline Cellulitis & 8 & 6.7 \\
\hline Local lymphadenopathy & 6 & 5.1 \\
\hline Necrosis & 3 & 2.5 \\
\hline Abscess & 2 & 1.7 \\
\hline Erysipelas & 1 & 0.8 \\
\hline Compartment syndrome & 1 & 0.8 \\
\hline \multicolumn{3}{|c|}{ Systemic symptoms/complications (118) } \\
\hline Blood coagulation change (103) & 85 & 82.5 \\
\hline Hemorrhages & 26 & 22.0 \\
\hline Acute renal failure & 6 & 5.1 \\
\hline Dyspnea & 2 & 1.7 \\
\hline Hemorrhagic stroke & 1 & 0.8 \\
\hline Septic shock & 1 & 0.8 \\
\hline Death & 1 & 0.8 \\
\hline
\end{tabular}

14.4\%) (Table 2). Thirteen cases were from Guajará (11\%), in Amazonas state (AM), and some cases were transferred from more distant or difficult-to-reach municipalities, such as Porto Walter (AC) (4 cases, 3.4\%), Tarauacá (AC) (4 cases, 3.4\%), Atalaia do Norte (AM) (2 cases, 1.7\%), Feijó (AC) (1 case, $0.8 \%$ ) e Jordão (AC) (1 case, $0.8 \%)$.

Most snakebites (65.8\%) occurred during the rainy season, but the correlations between the frequency of snakebites and rainfall and river level were non significant (respectively, $\mathrm{r}=$ $0.337 ; \mathrm{P}=0.285 ; \mathrm{n}=12$; and $\mathrm{r}=0.497 ; \mathrm{P}=0.100 ; \mathrm{n}=12$ ). (Table 1, Figure 3). Snakebites occurred mostly in the rural area $(85.7 \%$ of the cases). They were more frequent in males $(76.7 \%)$, in the $11-20$ years age group $(28.7 \%)$. Bites were predominantly on the foot $(67 \%)$ and the main victims were farmers (48\%) and children and teenagers (39\%) (Table 1).
Table 2. Clinical and epidemiological characteristics of cases of bothropic envenoming in the Juruá Regional Hospital, in the Municipality of Cruzeiro do Sul in the upper Juruá River region (western Brazilian Amazon), from July 2017 to June 2018, according to severity grade (mild, moderate or severe). Sample size is indicated in each case, in parentheses after the parameter. Data for number of ampoules are minimum - maximum followed by the average in parentheses. For other parameters values are the absolute numbers followed by the frequency (\%) in parentheses.

\begin{tabular}{|c|c|c|c|}
\hline Parameter & Mild & Moderate & Severe \\
\hline $\begin{array}{l}\text { Number of ampoules applied for } \\
\text { antivenom therapy (103) }\end{array}$ & $2-8(4.5)$ & $3-12(6.7)$ & $8-22(12.5)$ \\
\hline \multicolumn{4}{|l|}{ Time to hospital treatment (118) } \\
\hline$\leq 6$ hours & $43(65.2)$ & $20(30.3)$ & $3(4.5)$ \\
\hline$>6$ hours & $16(30.8)$ & $23(44.2)$ & $13(25)$ \\
\hline \multicolumn{4}{|l|}{ Ethnicity (118) } \\
\hline Indigenous (7) & $2(28.5)$ & $2(28.5)$ & $3(43)$ \\
\hline Non-Indigenous (111) & $57(51.3)$ & $41(37)$ & $13(11.7)$ \\
\hline \multicolumn{4}{|l|}{ Municipality (118) } \\
\hline Cruzeiro do Sul & $28(51.9)$ & $21(38.8)$ & $5(9.3)$ \\
\hline Mâncio Lima & $12(57.1)$ & $7(33.3)$ & $2(9.6)$ \\
\hline Rodrigues Alves & $10(58.8)$ & $5(29.5)$ & $2(11.7)$ \\
\hline Porto Walter & 0 & $03(75)$ & $1(25)$ \\
\hline Marechal Thaumaturgo & 0 & 0 & $1(100)$ \\
\hline Tarauacá & $4(100)$ & 0 & 0 \\
\hline Feijó & 0 & $1(100)$ & 0 \\
\hline Guajará & $5(38.5)$ & $5(38.5)$ & $3(23)$ \\
\hline Atalaia do Norte & 0 & $1(50)$ & $1(50)$ \\
\hline Jordão & 0 & 0 & $1(100)$ \\
\hline \multicolumn{4}{|l|}{ Type of land use (118) } \\
\hline Rural & $52(48)$ & $42(38)$ & $15(14)$ \\
\hline Urban & $7(78)$ & $1(11)$ & $1(11)$ \\
\hline \multicolumn{4}{|l|}{ Age group (118) } \\
\hline 0 to 10 & $7(54)$ & $2(15)$ & $4(31)$ \\
\hline 11 to 20 & $24(68,6)$ & $9(25.7)$ & $2(5.7)$ \\
\hline 21 to 30 & $6(33.3)$ & $10(55.5)$ & $2(11.2)$ \\
\hline 31 to 40 & $10(42)$ & $11(46)$ & $3(12)$ \\
\hline 41 to 50 & $8(47)$ & $7(41)$ & $2(12)$ \\
\hline 51 to 60 & $4(57)$ & $3(43)$ & 0 \\
\hline$>60$ & 0 & $1(25)$ & $3(75)$ \\
\hline \multicolumn{4}{|l|}{ Sex (118) } \\
\hline Male & $48(50)$ & $35(37)$ & $12(13)$ \\
\hline Female & $11(48)$ & $8(35)$ & $4(17)$ \\
\hline \multicolumn{4}{|l|}{ Anatomical region bitten (116) } \\
\hline Lower members & $50(51.5)$ & $33(34.1)$ & $14(14.4)$ \\
\hline Upper members & $6(37.5)$ & $9(56.2)$ & $1(6.3)$ \\
\hline Trunk & $1(50)$ & $1(50)$ & 0 \\
\hline Head & 0 & 0 & $1(100)$ \\
\hline
\end{tabular}

The majority (59.4\%) of snakebite cases were treated in less than six hours (Table 1). Pain and edema were the most frequent local manifestations (93.2\% of cases), followed by ecchymosis $(12.7 \%)$, bleeding at the site of the bite $(11 \%)$, blisters $(10.2 \%)$, secondary infection $(9 \%)$, cellulitis $(6 \%)$, regional lymphadenopathy $(5.1 \%)$, necrosis $(2.5 \%)$, abscess $(1.7 \%)$, erysipelas $(0.8 \%)$, and compartment syndrome 


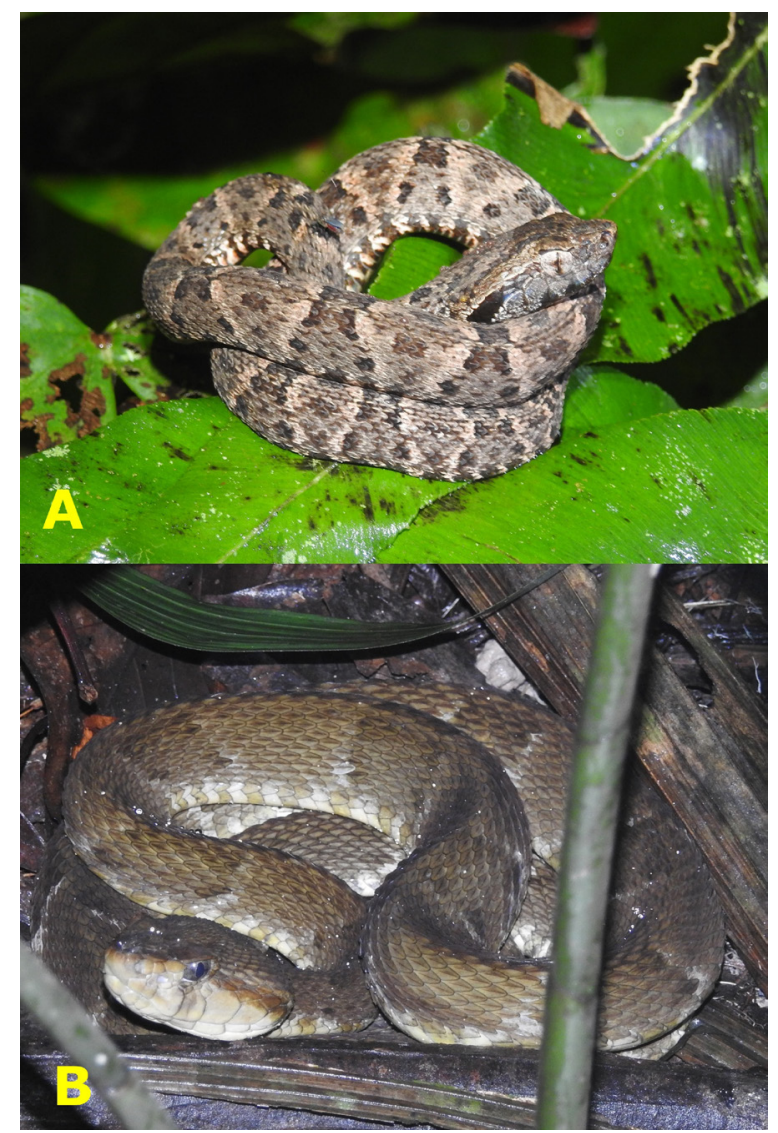

Figure 2. Jararaca or surucucu (Bothrops atrox), the snake responsible for envenomings in the present study in the upper Juruá River region. (A) Juvenile; (B) Adult. Credit: Paulo Sérgio Bernarde. This figure is in color in the electronic version.
$(0.8 \%)$ (Table 1, Figure 4). The most frequent systemic manifestations and complications were changes in blood coagulation time (82.5\% of 103 cases), bleeding (22\%) followed by acute renal failure (5.1\%), dyspnea (1.7\%), septic shock $(0.8 \%)$, and hemorrhagic stroke $(0.8 \%)$ (Table 1$)$.

Half of the cases were classified as mild, $36.5 \%$ as moderate and $13.5 \%$ as severe (Table 1 ). The severity of the snakebites was associated with the delay in receiving the antivenom therapy, as $65 \%$ of patients treated in less then six hours were mild cases, while almost $70 \%$ of patients treated in over six hours were moderate to severe cases (Table 2) (Chi-square test $=17.4, \mathrm{P}<0.001)$. There was a predominance of mild cases in patients from the urban area of Cruzeiro do Sul (78\% of cases) compared to those in the rural areas (48\%) (Table 2). The highest proportions of severe cases were observed in children aged 10 years or less (31\% of cases) and in the elderly $(75 \%)$ (Table 2) (Chi-square test $=27.94, \mathrm{P}=0.006)$. Indigenous patients $(\mathrm{n}=7)$ were the predominant severe cases $(43 \%)$ in relation to the non-indigenous population (11.7\%), however, there was no significant difference between the proportions (Table 2) $($ Chi-square test $=5.52, \mathrm{P}=0.063)$.

Of the 118 bothropic envenoming patients, 15 did not receive antivenom therapy, either because it was a mild case, more than seven days had elapsed since the snakebite, or insufficient clinical background information was available. The mean number of serum ampoules used in treatment varied from 4.5 in mild cases, to 6.7 in moderate cases, and 12.5 in severe cases (Table 2).

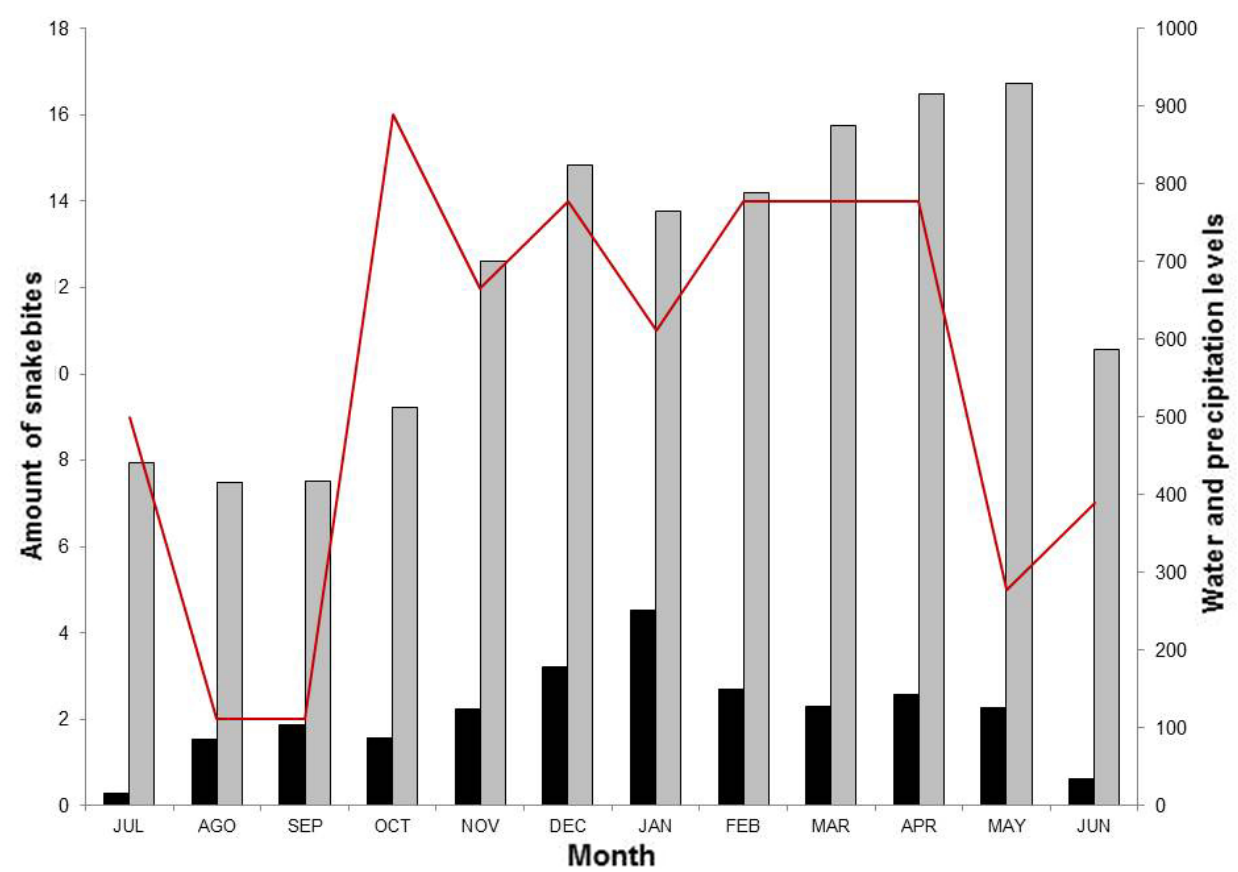

Figure 3. Monthly distribution of snakebites (red line), rainfall (black bars, values in mm), and water level of the Juruá River (grey bars, values in cm) from July 2017 to June 2018. This figure is in color in the electronic version. 


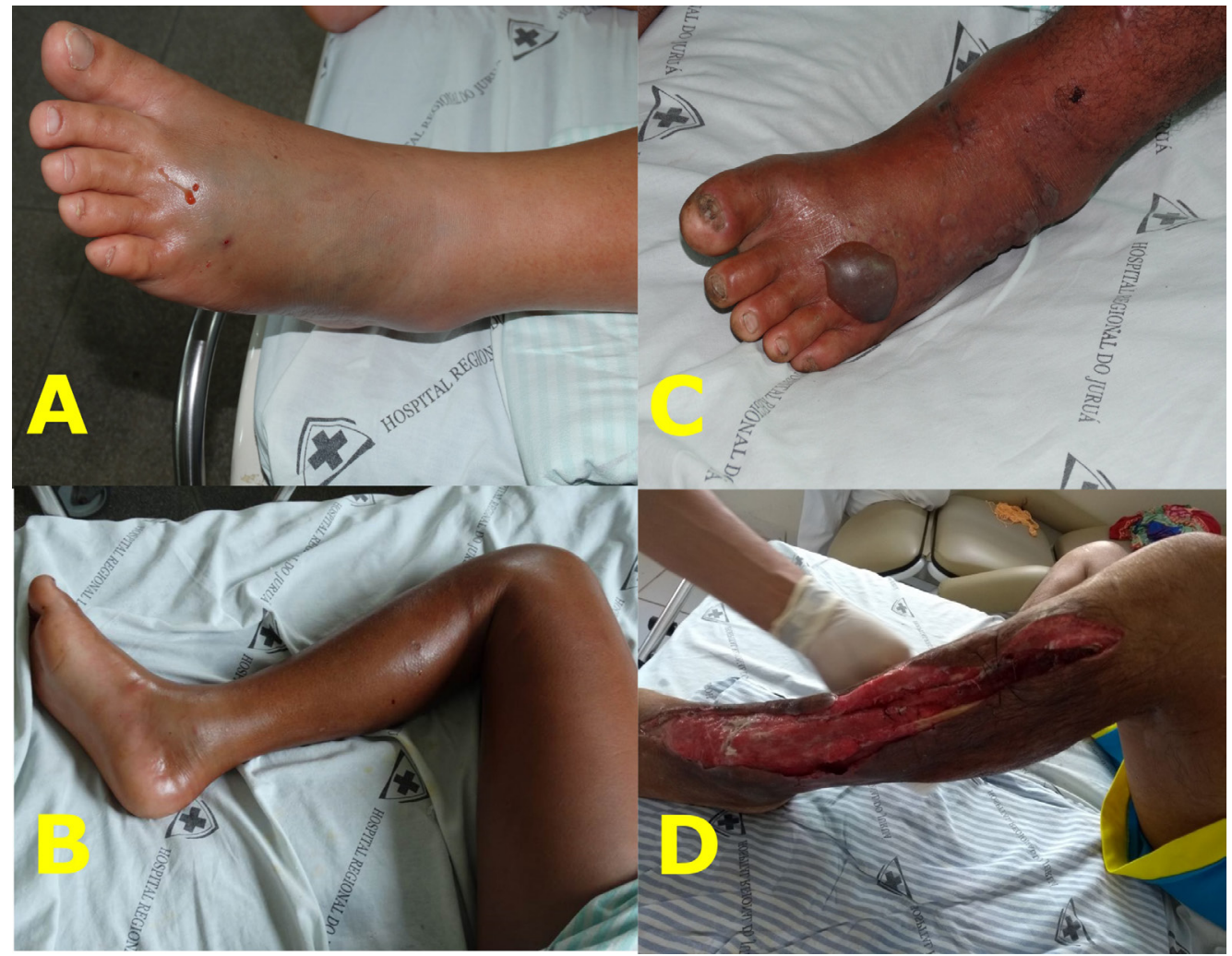

Figure 4. Evolution of Bothrops snakebite wounds in this study: (A) Foot with edema, ecchymosis and bleeding; (B) Leg with edema in three segments; (C) Foot with edema and blister; (D) Leg with necrosis. Credit: Ageane Mota da Silva. This figure is in color in the electronic version.

\section{DISCUSSION}

The morbidity coefficient in this study $(76.2$ cases per 100,000 inhabitants) was higher than that recorded for the nine states comprising Brazilian Amazonia (ranging from 25.2 to 75.3 per 100,000 inhabitants in Roraima and Mato Grosso, respectively; Magalhães et al. 2018). In the Brazilian Amazon, some of the highest incidences of snakebites on Earth were registered (over 200 cases per 100,000 inhabitants; Feitosa $e t$ al. 2015a). We recorded a higher morbidity coefficient in the upper Juruá region than that recorded for Acre state as a whole, the northern Brazilian region, and Brazil (61.1, 56.1 and 14.7 cases per 100,000 inhabitants, respectively) (Chippaux 2015). This points to a high prevalence of snakebites in the upper Juruá region, as previously reported by Pierini et al. (1996)

Except for cases of snakebites by non-venomous snakes, the exclusive occurrence of bothropic envenoming in our sample confirms the low frequency of lachetic and elapidic bites in Amazonia (Pardal et al. 2004; Moreno et al. 2005; Oliveira et al. 2018; Roriz et al. 2018). Our study also suggests that the frequency of lachetic snakebites (51\%) recorded in a previous study for Cruzeiro do Sul (Bernarde and Gomes 2012) was overestimated, probably due to that both Bothrops atrox and Lachesis muta are known by the common name "surucucu" in the region, which can lead health professionals to mistakenly diagnose bothropic as lachetic envenomings (Mota-da-Silva et al. 2019a). Bothrops atrox is the main snake species involved in envenomings in the upper Juruá region, as it was identified by $86.8 \%$ of the patients through photographs, comprosed $66.6 \%$ of the specimens that caused envenomings that were brought to the hospital, and was confirmed in $29 \%$ of the immunoenzymatic assays performed on patients' blood samples. This species presents a generalist diet, preying on various types of animals (rodents, amphibians, lizards, other snakes), and is the venomous snake most commonly found in forests, while also being the most tolerant to anthropisized areas (pasture, agriculture) (Turci $e t$ al. 2009; Bernarde et al. 2017). The species had already been identified in other studies as the cause of most snakebites in the upper Juruá region (Pierini et al. 1996; Bernarde and Gomes 2012; Mota-da-Silva et al. 2019a).

Snakebites tended to occur more often during the rainy season, corroborating other studies in Amazonia (Moreno et al. 2005; Bernarde and Gomes 2012; Feitosa et al. 2015a; Roriz et al. 2018). The lack of correlation between snakebite frequency and rainfall or river level in our study may be owed to stochasticity, as we analyzed data for only one year. In a previous study conducted in this region over two years, a positive correlation between snakebites and rainfall was observed (Bernarde and Gomes 2012). The rainy months 
coincide with the period of greater reproductive activity of the snakes (mating, birth of young; Martins and Oliveira 1998; Oliveira and Martins 2001; Almeida-Santos and Salomão 2002) and availability of their prey (Martins and Oliveira 1998; Oliveira and Martins 2001; Turci et al. 2009). At the same time, the flooding of rivers and lakes drives snakes to seek drier places, increasing encounters with humans, as certain human activities are also more frequent during this period (planting and harvesting, extractivism of forest products, hunting) (Pierini et al. 1996; Moreno et al. 2005; Waldez and Vogt 2009; Feitosa et al. 2015a; Mota-da-Silva et al. 2019b).

The general epidemiological profile of the victims registered in our study (the majority of victims were male, living in rural areas and were bitten on lower limbs) corresponds to what has been observed in other studies on snakebites in Amazonia (Moreno et al. 2005; Magalhães et al. 2018). The proportion of younger victims in our study (39\% under 20 years of age) was higher than that recorded by Magalhães et al. (2018) for Brazilian Amazonia. The predominance of bites on the feet ( $67 \%$ of the cases) and on the legs $(17 \%)$ reinforces the importance of the use of boots or leggings during rural and extractivist activities, as a preventative measure against snakebites (Oliveira et al. 2018). Snakebites involving the upper regions of the body (14.4\% of cases), could be associated, in some cases, with the presence of Bothrops bilineatus smaragdinus and young B. atrox in the vegetation, the most frequently found Bothrops individuals in forested floodplains of the upper Juruá (Turci et al. 2009; Fonseca et al. 2019). As observed by Moreno et al. (2005) in the region of Rio Branco (capital of Acre state), the main snakebite victims in our study were farmers, highlighting the ocupational correlate of snakebite morbidity with agriculture (Mise et al. 2019), and children and teenagers, confirming these groups as those at higher risk, and which should be primary targets of prevention campaigns.

The time elapsed between the snakebite and hospital care was lower in our study than that recorded by Bernarde and Gomes (2012) in previous years for the same region $(53.6 \%$ treated in less than six hours and $27 \%$ after 24 hours, against $60 \%$ and $11.3 \%$, respectively, in our study). This decrease in time to treatment may be due to the increase in the number of ambulances in Acre after 2015 (O’Dwyer et al. 2017), as well as to improvements in road infrastructure and telephone services, increasing the accessibility of patients to healthcare providers. The majority of mild cases in our study (43 of 59 cases, $73 \%$ ) were among those treated in less than six hours, while 13 of 16 severe cases $(81 \%)$ were among those treated after more than six hours had passed, which points to that longer delays in getting antivenom therapy are associated with an enhanced severity of sintomatology, including serious complications and death (Feitosa et al. 2015b; Mise et al. 2018; Roriz et al. 2018).
The frequency of mild, moderate and severe bothropic envenoming in our study $(50,36.5$ and $13.5 \%$, respectively), differed somewhat from that reported for the capital city of Acre state, Rio Branco (31.2, 48.6 and 20.2\%) (Moreno et al. 2005). Severity frequencies were also reported for other Amazonian urban centers, such as Porto Velho (23.9, 26.1 and 50\%), also in the southwestern Amazon (Roriz et al. 2018), Manaus (27.7, 54.2 and 18.1\%), in the central Amazon (Oliveira et al. 2019), and Belém (58.1, 36.5 and 5.4\%), in the eastern Amazon (Pardal et al. 2004). These figures depend on the criteria used to define severity grades and the local context of accessibility to healthcare (Feitosa et al., 2015b), but may also be related to regional variations in the venom of Bothrops atrox (Núñez et al. 2009; Sousa et al. 2013; DelRei et al. 2019).

The most frequently observed symptoms in our study (pain and edema) are the most commonly observed in bothropic envenomings (Oliveira et al. 2018). Other symptoms and complications observed less frequently, such as hemorrhage, renal failure and septic shock, are also typical of bothropic envenoming (Souza 2002; Pardal et al. 2004; Oliveira et al. 2018; Roriz et al. 2018). Altered blood clotting time had been observed in $43.1 \%$ to $72.2 \%$ cases of Bothrops envenomings in the Brazilian Amazon (Souza 2002; Pardal et al. 2004; Moreno et al. 2005; Oliveira et al. 2019). The frequency in our study $(82.5 \%)$ was more similar to that reported for Colombia (84.6\%; Otero et al. 1996). In Ecuador, 95\% cases were reported with altered blood clotting (Smalligan et al. 2004). These varying frequencies may owe to regional differences in B. atrox venom (Núñez et al. 2009; Sousa et al. 2013; Del-Rei et al. 2019) or that different Bothrops species were present in the study areas. For example, $B$. atrox and $B$. bilineatus smaragdinus caused, respectively, $45 \%$ and $36 \%$ of the envenomings in Pastaza (Ecuadorian Amazon), while $B$. atrox caused most of snakebites in other studies (Souza 2002; Pardal et al. 2004; Moreno et al. 2005; Roriz et al. 2018).

In the state of Amazonas, indigenous patients had higher lethality risk from snakebites than non-indigenous patients (Souza et al. 2018), a tendency which we also observed in our study. In addition to more precarious access to health services from indigenous communities, they probably also resort more frequently to traditional treatments instead of seeking medical attention (Pierini et al. 1996), and only look for a hospital when the snakebite symptoms get more serious.

\section{CONCLUSIONS}

Snakebite is a significant health problem in the upper Juruá region, reaching mainly farmers, children and teenagers in rural and forested areas. The main species of venomous snake involved in snakebites was Bothrops atrox, and snakebites occur more during the rainy season. The delay of the antivenom therapy due to the great distance of the localities where the bites occur and the hospital care was a problem associated with 
the severity of the cases. It is suggested educational campaigns for populations most vulnerable to snakebites to reduce this degree of morbidity in the western Brazilian Amazonia.

\section{ACKNOWLEDGMENTS}

We are grateful to the directors of the Juruá Regional Hospital of Cruzeiro do Sul for the permission for this research and the entire team of doctors, nurses, nursing assistants and other hospital staff for their support in this study.

\section{REFERENCES}

ACRE. 2010. Governo do Estado do Acre. Zoneamento EcológicoEconômico do Estado do Acre, Fase II (Escala 1:250.000): Documento Síntese. 2nd. ed. Secretaria Estadual de Meio Ambiente, Rio Branco. 356p.

Almeida-Santos, S.M.; Salomão, M.G. 2002. Reproduction in Neotropical pitvipers, with emphasis on species of the genus Bothrops. In: Schuett, G.W.; Hoggren, M.; Douglas, M.E.; Greene, H.W. (Org.). Biology of the Vipers. v.1. Eagle Mountain Publishing, Carmel, Indiana, p.445-462.

ANA. 2019. Agência Nacional de Águas (http://estacoespnqa.ana. gov.br/estacoes.aspx). Accessed on 18/03/2019.

Bernarde, P.S. 2014. Serpentes peçonhentas e acidentes ofidicos no Brasil. 1st ed. Anolis Books, Curitiba, 223p.

Bernarde, P.S.; Gomes, J.O. 2012. Serpentes peçonhentas e ofidismo em Cruzeiro do Sul, Alto Juruá, Estado do Acre, Brasil. Acta Amazonica, 42: 65-72.

Bernarde, P.S.; Turci, L.C.B.; Machado, R.A. 2017. Serpentes do Alto Juruá, Acre - Amazônia Brasileira. EDUFAC, Rio Branco, 166p.

Bernarde, P.S.; Turci, L.C.B.; Abegg, A.D.; Franco, F.L. 2018. A remarkable new species of coral snake of the Micrurus hemprichii species group from the Brazilian Amazon. Salamandra, 54: 249-258.

Chippaux, J.P. 2015. Epidemiology of envenomations by terrestrial venomous animals in Brazil based on case reporting: from obvious facts to contingencies. Journal of Venomous Animals and Toxins Including Tropical Diseases, 21: 13.

Chippaux, J.P. 2017. Incidence and mortality due to snakebite in the Americas. PLOS Neglected Tropical Diseases, 11: e0005662.

Colombini, M.; Fernandes, I.; Cardoso, D.F.; Moura-da-Silva, A.M. 2001. Lachesis muta muta venom: immunological differences compared with Bothrops atrox venom and importance of specific antivenom therapy. Toxicon, 39: 711-719.

Costa, H.C.; Bérnils, R.S. 2018. Répteis do Brasil e suas Unidades Federativas: Lista de espécies. Herpetologia Brasileira, 7: 11-57.

Cunha, O.R.; Nascimento, F.P. 1993. Ofídios da Amazônia: As cobras da regiāo Leste do Pará. Boletim do Museu Paraense Emílio Goeldi, Série. Zoologia, 9: 1-191.

Del-Rei, T.H.M.; Sousa, L.F.; Rocha, M.M.T.; Freitas-de-Sousa, L.A.; Travaglia-Cardoso, S.R.; Grego, K; Sant'Anna, S.S.; Chalkidis, H.M.; Moura-da-Silva, A.M. 2019. Functional variability of Bothrops atrox venoms from three distinct areas across the Brazilian Amazon and consequences for human envenomings. Toxicon, 164: 61-70.
Fan, H.W.; Monteiro, W.M. 2018. History and perspectives on how to ensure antivenom accessibility in the most remote areas in Brazil. Toxicon, 151: 15-23.

Feitosa, E.; Sampaio, V.; Sachett, J.; Castro, D.B.; Noronha, M.D.N.; Lozano, J.L.L.; et al. 2015a. Snakebites as a largely neglected problem in the Brazilian Amazon: highlights of the epidemiological trends in the State of Amazonas. Revista da Sociedade Brasileira de Medicina Tropical, 48: 34-41.

Feitosa, E.L.; Sampaio, S.V.; Salinas, J.L.; Queiroz, A.M.; Silva, I.M.; Gomes, A.A.; et al. 2015b. Older age and time to medical assistance are associates with severity and mortality of snakebites in the Braziian Amazon: a case- control study. PLoS ONE, 10: e0132237.

Fonseca, W.L.; Correa, R.R.; Oliveira, A.S.; Bernarde, P.S. 2019. Caudal luring in the Neotropical two-striped forest pitviper Bothrops bilineatus smaragdinus Hoge, 1966 in the western Amazon. Herpetology Notes, 12: 365-374.

Gutiérrez, J.M. 2014. Reducing the impact of snakebite envenoming in Latin America and the Caribbean: achievements and challenges ahead. Transactions of The Royal Society of Tropical Medicine and Hygiene, 108: 530-537.

IBGE. 2019. Instituto Brasileiro de Geografia e Estatística. Censo demográfico. Instituto Brasileiro de Geografia e Estatística (2018) Censo Demográfico. (www.ibge.gov.br). Accessed on 20/01/2019.

INMET. 2019. Instituto Nacional de Meteorologia. (http://www. inmet.gov.br). Accessed on 20/01/2019.

Lima, A.C.S.F.; Campos, C.E.C; Ribeiro, J.R. 2009. Perfil epidemiológico de acidentes ofídicos do Estado do Amapá. Revista da Sociedade Brasileira de Medicina Tropical, 42: 329-335.

Magalhães, S.F.V.; Peixoto, H.M.; Moura, N.; Monteiro, W.M.; Oliveira, M.R.F. 2019. Snakebite envenomation in the Brazilian Amazon: a descriptive study. Transactions of The Royal Society of Tropical Medicine and Hygiene, 113: 143-151.

Martins, M.; Oliveira, M.E. 1998. Natural history of snakes in forests of the Manaus region, Central Amazonia, Brazil. Herpetological Natural History, 6: 78-150.

Mendonça-da-Silva, I.; Tavares, A.M.; Sachett, J.; Sardinha, J.F.; Zaparolli, L.; Santos, M.F.G.; Lacerda, M.; Monteiro, W.M. 2017. Safety and efficacy of a freeze-dried trivalent antivenom for snakebites in the Brazilian Amazon: an open randomized controlled phase IIb clinical trial. PLOS Neglected Tropical Diseases, 11: e0006068.

Ministério da Saúde. 2016. Secretaria de Vigilância em Saúde. Nota Informativa No 25, de 2016-CGDT/DEVIT/SVS/MS. (http:// www.saude.pr.gov.br/arquivos/File/NotaInformativa_25_ MS.pdf). Accessed on 10/02/2017.

Mise, Y.F.; Lira-da-Silva, R.M.; Carvalho, F.M. 2018. Time to treatment and severity of snake envenoming in Brazil. Revista Panamericana de Salud Pública, 42: e52.

Mise, Y.F.; Lira-da-Silva, R.M.; Carvalho, F.M. 2019. Fatal Snakebite Envenoming and Agricultural Work in Brazil: A Case-Control Study. American Journal of Tropical Medicine and Hygiene, 100: 150-154.

Moreira, J.G.V.; Aquino, A.P.V.; Mesquita, A.A.; Muniz, M.A.; Serrano, R.O.P. 2019. Stationarity in annual daily maximum streamflow series in the upper Juruá River, western Amazon. Revista Brasileira de Geografia Física, 12: 705-713. 
Moreno, E.; Queiroz-Andrade, M.; Lira-da-Silva, R.M.; TavaresNeto, J. 2005. Características clínico epidemiológicas dos acidentes ofídicos em Rio Branco, Acre. Revista da Sociedade Brasileira de Medicina Tropical, 38: 15-21.

Mota-da-Silva, A.; Monteiro, W.M.; Bernarde, P.S. 2019a. Popular names for bushmaster (Lachesis muta) and lancehead (Bothrops atrox) snakes in the Alto Juruá region: repercussion to clinicalepidemiological diagnosis and surveillance. Revista da Sociedade Brasileira de Medicina Tropical, 52: e-20180140.

Mota-da-Silva, A.; Sachett, J.; Monteiro, W.M.; Bernarde, P.S. 2019 b. Extractivism of palm tree fruits: A risky activity because of snakebites in the state of Acre, Western Brazilian Amazon. Revista da Sociedade Brasileira de Medicina Tropical, 52: e-20180195.

Nicoleti, A.F.; Medeiros, C.R.; Duarte, M.R.; França, F.O.S. 2010. Comparison of Bothropoides jararaca bites with and without envenoming treated at the Vital Brasil Hospital of the Butantan Institute, State of São Paulo, Brazil. Revista da Sociedade Brasileira de Medicina Tropical, 43: 657-661.

Núñez, V.; Cid, P.; Sanz, L.; Torre, P.; Angulo, Y.; Lomonte, B.; et al. 2009. Snake venomics and antivenomics of Bothrops atrox venoms from Colombia and the Amazon regions of Brazil, Perú and Ecuador suggest the occurrence of geographic variation of venom phenotype by a trend towards paedomorphism. Journal of Proteomics, 73: 57-78.

O’Dwyer, G.; Konder, M.T.; Reciputti, L.P.; Macedo, C.; Lopes, M.G.M. 2017. O processo de implantação do Serviço de Atendimento Móvel de Urgência no Brasil: estratégias de ação e dimensóes estruturais. Cadernos de Saúde Pública, 33: e00043716.

Oliveira, M.E.; Martins, M. 2001. When and where to find a pitviper: activity patterns and habitat use of the lancehead, Bothrops atrox, in central Amazonia, Brazil. Herpetological Natural History, 8: 101-110.

Oliveira, S.S.; Sampaio, V.S.; Sachett, J.A.G.; Alves, E.C.; Silva, V.C.; Lima, J.A.A.; et al. 2018. Snakebites in the Brazilian Amazon: current knowledge and perspectives. In: Vogel, C.W.; Seifert, S.A.; Tambourgi, D.V. (Org.). Clinical Toxinology in Australia, Europe, and Americas. Toxinology. v.1. Springer Publishing, New York, p.73-99.

Oliveira, S,S.; Alves, E.C.; Santos, A.S.; Pereira, J.P.T.; Sarraff, L.K.S.; Nascimento, E.F.; et al. 2019. Factors associated with systemic bleeding in Bothrops envenomation in a tertiary hospital in the Brazilian Amazon. Toxins, 7: E22.

Otero, R.; Gutiérrez, J.M.; Núnez, V.; Robles, A.; Estrada, R.; Segura, E.; et al. 1996. A randomized double-blind clinical trial of two antivenoms in patients bitten by Bothrops atrox in Colombia. Transactions of The Royal Society of Tropical Medicine and Hygiene, 90: 696-700.

Pardal, P.P.; Souza, S.M.; Monteiro, M.R.; Fan, H.W.; Cardoso, J.L.; França, F.O.; et al. 2004. Clinical trial of two antivenoms for the treatment of Bothrops and Lachesis bites in the north eastern Amazon region of Brazil. Transactions of The Royal Society of Tropical Medicine and Hygiene, 98: 28-42.

Pierini, S.V.; Warell, D.A.; De Paulo. A. 1996. Theakston RDG. High incidence of bites and stings by snakes and other animals among rubber tappers and Amazonian indians of the Juruá Valley, Acre state, Brazil. Toxicon, 34: 225-36.

Rahman, R; Faiz, M.A.; Rahman, B.; Bashe, A.; Jones, A.; D’Este, C.; et al. 2010. Annual incidence of snake bite in rural Bangladesh. PLOS Neglected Tropical Diseases, 4: e860.

Roriz, K.R.P.S.; Zaqueo, K.D.; Setubal, S.S.; Katsuragawa, T.H.; Silva, R.R.D.; Fernandes, C.F.C.; et al. 2018. Epidemiological study of snakebite cases in Brazilian Western Amazonia. Revista da Sociedade Brasileira de Medicina Tropical, 51: 338-346.

Santos, H.L.R.; Sousa, J.D.B.; Alcântara, J.A.; Sachett, J.A.G.; Villas Boas, T.S.; Saraiva, I.; et al. 2019. Rattlesnakes bites in the Brazilian Amazon: clinical epidemiology, spatial distribution and ecological determinants. Acta Tropica, 191:61-76.

Sharma, S.K.; Chappuis, F.; Jha, N.; Bovier, P.A.; Loutan, L.; Koirala, S. 2004. Impact of snakebites and determinants of fatal outcomes in Southeastern Nepal. The American Journal of Tropical Medicine and Hygiene, 71: 234-238

Silveira, P.V.P.; Nishioka, S.A. 1992. Non-venomous snake bite and snake bite withthout envenoming in a Brazilian teaching hospital, analysis of 91 cases. Revista do Instituto de Medicina Tropical de São Paulo, 34: 499-503.

Smalligan, R.; Cole, J.; Brito, N.; Laing, G.D.; Mertz, B.L.; Manock, S.; et al. 2004. Crotaline snake bite in the Ecuadorian Amazon: randomized double blind comparative trial of three South American polyspecific antivenoms. British Medical Journal, 329: 1129.

Souza, A.R.B. 2002. Snakebite by Bothrops atrox (Lin. 1758) in the State of Amazonas - Brazil: study of 212 cases with identified snake. Revista de Patologia Tropical, 31: 267-268.

Sousa, L.F.; Nicolau, C.A.; Peixoto, P.S.; Bernardoni, J.L.; Oliveira, S.S.; Portes-Junior, J.A.; et al. 2013. Comparison of phylogeny, venom composition and neutralization by antivenom in diverse species of Bothrops complex. PLOS Neglected Tropical Diseases, 7: e2442.

Souza, A.S.; Sachett, J.; Alcântara, J.A.G.; Freire, M.; Alecrim, M.D.G.C.; Lacerda, M.; et al. 2018. Snakebites as cause of deaths in the Western Brazilian Amazon: Why and who dies? Deaths from snakebites in the Amazon. Toxicon, 145: 15-24.

Turci, L.C.B.; Albuquerque, S.; Bernarde, P.S.; Miranda, D.B. 2009. Uso do hábitat, atividade e comportamento de Bothriopsis bilineatus e de Bothrops atrox (Serpentes: Viperidae) na floresta do Rio Moa, Acre, Brasil. Biota Neotropica, 9: 197-206.

Waldez, F.; Vogt, R.C. 2009. Aspectos ecológicos e epidemiológicos de acidentes ofídicos em comunidades ribeirinhas do baixo rio Purus, Amazonas, Brasil. Acta Amazonica, 39: 681-692.

Williams, D.J.; Faiz, M.A.; Abela-Ridder, B.; Ainsworth, S.; Bulfone, T.C.; Nickerson A.D.; et al. 2019. Strategy for a globally coordinated response to a priority neglected tropical disease: Snakebite envenoming. PLOS Neglected Tropical Diseases, 13: e0007059.

\section{RECEIVED: $19 / 04 / 2019$ \\ ACCEPTED: $12 / 09 / 2019$ \\ ASSOCIATE EDITOR: Claudia Keller}

